\title{
Short-term Salt-shock Effects on Tomato Fruit Quality, Yield, and Vegetative Prediction of Subsequent Fruit Quality
}

\author{
Carl E. Niedziela, Jr. ${ }^{1}$, Paul V. Nelson ${ }^{2}$, Daniel H. Willits ${ }^{3}$, and Mary M. Peet ${ }^{4}$ \\ Department of Horticultural Science, North Carolina State University, Raleigh, NC 27695-7609
}

Additional index words. Lycopersicon esculentum, citrate, fruit, greenhouse, hydroponics, malate, nutrient film technique, plant nutrition, salt-stress, water relations

\begin{abstract}
Commercial recommendations exist for using short-term salt-shocks on tomato (Lycopersicon esculentum Mill.) to improve fruit quality. Six experiments were conducted to 1) assess the influence of nutrient concentration and short-term salt-shocks on fruit quality and yield and 2) identify a vegetative predictor of subsequent fruit quality. The first objective was addressed in three nutrient film technique (NFT) experiments (Expts. 1-3). Four treatments were applied: two maintained constant at two baseline concentrations ( $0.25 \mathrm{X}$ and $1 \mathrm{X}$-commercial level) and two provided salt-shock periods of $30 \mathrm{~min}$, twice daily. There were no effects of baseline concentration or salt-shocks on total number and weight of marketable fruit. Fruit quality was better at the 1X baseline concentration as observed by higher titratable acidity (Expt. 2), higher percent dry matter (Expts. 2 and 3), higher soluble solids concentration (Expt. 2), and lower pH (Expts. 2 and 3), however, weight per marketable fruit was lower (Expt. 2). Salt-shocks had little effect on fruit quality, refuting its commercial potential. Salt-shocks decreased fruit pH (Expts. 1 and 3). However, titratable acidity increased at the $0.25 X$ level and decreased at the 1X level (Expt. 3). In Expt. 2, but not in Expt. 3, citrate concentration in the fifth leaf from the apex of young vegetative plants was correlated with subsequent fruit quality. Three additional experiments in static hydroponics with vegetative plants showed no significant differences in leaf citrate levels due to a single, short-term salt-shock. Thus, citrate is not a good predictor of fruit quality.
\end{abstract}

Plants and other organisms adapt to reduced water availability, caused by salinity, drought, and extreme temperatures, through osmoregulation. Various C compounds (soluble carbohydrates, organic acids, polyols), nitrogenous compounds (amino acids, tertiary nitrogenous compounds), and inorganic ions accumulate under stress conditions (Rains and Valentine, 1980). Increases in some of these compounds, such as sugars and organic acids, improve tomato fruit quality (Davies and Hobson, 1981).

Increased fertilizer or nonfertilizer salt concentrations in the root media for extended periods has been reported to improve tomato fruit quality in field culture (Mitchell et al., 1991; Mizrahi and Pasternak, 1985), sand culture (Mizrahi et al., 1988), static hydroponics (Mizrahi, 1982; Mizrahi et al., 1986), and NFT (Gough and Hobson, 1990; Massey et al., 1984). Although saltstress has been shown to improve fruit quality, yield is often reduced (Adams and Ho, 1989; Mizrahi and Pasternak, 1985; Massey et al., 1984). To minimize this problem, hydroponic growers are sometimes advised to vary salt levels with developmental stages. A technical bulletin (ICI Midox, n.d.) recommends increasing the electrical conductivity (EC) of the nutrient solution from 1.5 to $2.0 \mathrm{mS} \cdot \mathrm{cm}^{-1}$ to 3 to $5 \mathrm{mS} \cdot \mathrm{cm}^{-1}$, in 0.5

Received for publication 12 Dec. 1991. Accepted for publication 29 July 1992. This research was funded in part by the North Carolina Agr. Res. Serv. (NCARS), Raleigh, NC 27695-7643. Use of trade names in this publication does not imply endorsement by the NCARS of products named nor criticism of similar ones not mentioned. Assistance of R.F. McFeeters, D.M. Pharr, W.A. Jackson, and N.C. Mingis is gratefully appreciated. From a thesis submitted by C.E.N. in partial fulfillment of the requirements for the $\mathrm{PhD}$ degree. The cost of publishing this paper was defrayed in part by the payment of page charges. Under postal regulations, this paper therefore must be hereby marked advertisement solely to indicate this fact.

${ }^{1}$ Graduate Research Assistant. Present address: Cooperative Extension Program, North Carolina Agricultural and Technical State Univ.. Greensboro. NC 274201928.

${ }^{2}$ Professor.

${ }^{3}$ Professor, Dept. of Biological and Agricultural Engineering.

${ }^{4}$ Associate Professor.
$\mathrm{mS} \cdot \mathrm{cm}^{-1}$ weekly increments until 2 weeks after the first harvest. The solution concentration is then lowered immediately and maintained at initial concentration. Massey et al. (1984) observed less yield decrease due to high salt level when the EC was allowed to decline from the high EC level to $2 \mathrm{mS} \cdot \mathrm{cm}^{-1}$ after the eighth harvest.

Another method suggested to increase fruit quality without decreasing yield is to use daily high salt pulses (Cooper, 1985). For the purposes of our paper, a pulse is a short-term (30 min) increase in the osmotic concentration of the root bathing solution. One commercial NFT system uses 30 min pulses 3 times daily (Cooper, 1985; Edwards, 1985). The effects of daily daynight shifts in EC on plant growth (Bruggink et al., 1987), yield, fruit quality, and $\mathrm{Ca}^{2+}$ accumulation (Adams and Ho, 1989) have been described. Adams and Ho (1989) observed that fluctuating the salinity from $8 \mathrm{mS} \cdot \mathrm{cm}^{-1}$ during the day to $3 \mathrm{mS} \cdot \mathrm{cm}^{-1}$ at night gave no yield advantage over maintaining the salinity constant at $5.5 \mathrm{mS} \cdot \mathrm{cm}^{-1}$ (the mean of 3 and $8 \mathrm{mS} \cdot \mathrm{cm}^{-1}$ ). However, the effects of short-term $(30 \mathrm{~min})$ salt-shocks on tomato fruit quality and yield have not been documented in the scientific literature.

A major difficulty in conducting tomato fruit quality studies is that it takes $\approx 3$ months from seeding until the first fruit begins to ripen. Since some of the same compounds (organic acids and sugars) that contribute to fruit quality are osmolytes in both fruit and leaves (Davies and Hobson, 1981; Rains and Valentine, 1980), it follows that these same chemicals might be used as vegetative predictors of subsequent fruit quality. If a vegetative predictor for the subsequent fruit quality could be identified, many hypotheses could be rapidly tested and the production systems improved.

Summarized in this paper are our findings on the effects of repeated short-term salt-shocks at two baseline nutrient concen-

Abbreviations: DAS, days after seeding; EC, electrical conductivity; NFT, nutrient film technique; SSC, soluble solids concentration. 
trations on fruit quality and yield. Also, the feasibility of using several possible vegetative predictors for subsequent tomato fruit quality is investigated.

\section{Materials and Methods}

General. Tomato ('Laura') seeds were sown in steam pasteurized quartz sand in a greenhouse. Following germination, plants were irrigated with a solution containing $0.5 \mathrm{X}$ macronutrient and $1 \mathrm{X}$ micronutrient concentrations of the specific hydroponic solution described in each experiment. Plants were removed from the sand and roots were washed in tap water before being placed in hydroponics. All experiments were conducted in a glass greenhouse. The heating system was set to activate at $18 \mathrm{C}$ at night, and cooling was started at $24 \mathrm{C}$ during the day. Six experiments were conducted. Three were conducted through fruiting in an NFT system and three were conducted with vegetative plants in a static hydroponic system.

NFT system for Expts. 1-3. Nutrient solutions were circulated from holding tanks with a submersible pump (NK-1, The Little Giant Pump Co., Oklahoma City, Okla.) through wooden troughs lined with a coextruded, white on black, $0.1-\mathrm{mm}$ polyethylene copolymer, layflat tubes (Hydro-gardens, Colorado Springs, Colo.). Each trough was $24 \times 155 \mathrm{~cm}$ and contained two tomato plants spaced $61 \mathrm{~cm}$ apart in the trough with $41 \mathrm{~cm}$ between trough centers. A single guard row was placed at the same spacing, parallel to the troughs, at each end of the greenhouse bench. In Expts. 2 and 3, two additional plants were evenly spaced between the two plants in each trough. The inner plants were later removed for vegetative analysis. Each trough was sloped at 18.5:1 for drainage. After flowing down the trough, solutions returned to their respective holding tanks.

Solutions in all treatments were circulated intermittently (10 min on : $10 \mathrm{~min}$ off). Pulse treatments were applied at 0900 and $1400 \mathrm{HR}$ for $30 \mathrm{~min}$. The system was controlled by a mechanical timing apparatus.

Solution $\mathrm{pH}$ and EC were monitored daily. The $\mathrm{pH}$ was adjusted with $0.5 \mathrm{~N} \mathrm{NaOH}$ or $0.5 \mathrm{~N} \mathrm{H}_{2} \mathrm{SO}_{4}$ to $5.8 \pm 0.2$ for all solutions. The EC was adjusted by nutrient addition or water dilution when solutions reached $\pm 25 \%$ of the initial concentration. Solution levels were controlled with a float valve connected to the water supply. All tanks were emptied and replaced with new solutions every 2 weeks.

Pulsing-1X and $4 X$ solution; fruit analyzed (Expt. 1). Seeds were sown on 2 Feb. 1989. Seedlings were irrigated with $0.5 \mathrm{X}$ solution beginning 8 days after seeding (DAS). Seedlings were

Table 1. Mean pH, titratable acidity, percent dry matter, SSC, and weight per marketable fruit for first cluster fruit of Expt. $1{ }^{\mathrm{z}}$

\begin{tabular}{|c|c|c|c|}
\hline \multirow[b]{2}{*}{ Pulsing } & \multirow[b]{2}{*}{$\mathrm{pH}$} & \multicolumn{2}{|c|}{$\begin{array}{c}\text { Titratable } \\
\text { acidity } \\
\text { (meq. } 100 \mathrm{ml}^{-1} \text { ) } \\
\text { baseline } \\
\text { nutrient concn }\end{array}$} \\
\hline & & $0.25 \mathrm{X}$ & $1 \mathrm{X}^{\mathrm{y}}$ \\
\hline No pulse & 4.21 & 7.31 & 7.58 \\
\hline Pulse $e^{x}$ & 4.18 & 7.42 & 7.27 \\
\hline Significance $^{\mathrm{w}}$ & 0.03 & 0.04 & 0.01 \\
\hline
\end{tabular}

${ }^{\mathrm{z}}$ Means for $\mathrm{pH}$ averaged over baseline nutrient concentrations.

${ }^{\mathrm{y}}$ The $1 \mathrm{X}$ nutrient solution was based on commercial recommendations.

${ }^{\mathrm{x}}$ Pulse treatment is an increase of four times the baseline nutrient concentration, twice daily for $30 \mathrm{~min}$.

${ }^{\mathrm{w}} \mathrm{p}$ values of $\mathrm{F}$ test; $\mathrm{H}_{\mathrm{o}}$ : Equal means. transferred to the NFT system 45 DAS. Once placed in the NFT system, plants were allowed to acclimate to their respective nutrient solutions before high EC pulses began 54 DAS. There were two treatments with a baseline concentration of $0.25 \mathrm{X}$ and two with a baseline concentration of $1 \mathrm{X}$. One treatment from each baseline group was pulsed at a concentration 4 times the baseline (i.e., $1 \mathrm{X}$ for the $0.25 \mathrm{X}$ baseline and $4 \mathrm{X}$ for the $1 \mathrm{X}$ baseline). The $1 \mathrm{X}$ solution for this study was based on a commercial NFT solution for growing tomatoes (Hall and Wilson, 1986). The macronutrient and $\mathrm{Cl}$ - concentrations (millimolars) in the $1 \mathrm{X}$ solution were $13 \mathrm{NO} \overline{3}, 2 \mathrm{NH}_{4}, 1.5 \mathrm{H}_{2} \mathrm{PO}_{4}^{-}, 7.7$ $\mathrm{K}+, 4 \mathrm{Ca}^{2+}, 2 \mathrm{Mg}^{2+} 2 \mathrm{SO}_{4}^{2-}$, and $3.2 \mathrm{Cl}^{-}$. Macronutrient and $\mathrm{Cl}^{-}$ratios were adjusted proportionally in other solution concentrations. Micronutrient concentrations (micromolars), except $\mathrm{Cl}^{-}$, were $107 \mathrm{Fe}^{3+}, 32 \mathrm{BO}_{3}^{3-}, 18 \mathrm{Mn}^{2+}, 1.6 \mathrm{Cu}^{2+}, 1.5 \mathrm{Zn}^{2+}$, and $0.6 \mathrm{MoO}_{4}^{2}$-in all solutions. Each plant was pollinated mechanically and fruit were harvested daily at incipient red. A structural failure of the overhead wire supports occurred 119 DAS resulting in the loss of several plants. The experiment was. terminated at this point, and data were collected only from the first fruit cluster.

Pulsing- $1 X$ and $4 X$ solution: Ca-enriched; fruit and leaves analyzed (Expt. 2). Seeds were sown on 16 Aug. 1989. Seedlings were irrigated with $0.5 \mathrm{X}$ solution beginning $14 \mathrm{DAS}$. Seedlings were transferred to the NFT system 50 DAS. High EC pulses began 57 DAS. The solutions and treatments for this study were the same as Expt. 1 except for the following changes: $\mathrm{Ca}^{2+}$ was increased in the $1 \mathrm{X}$ solution to $5 \mathrm{mM}$ and $\mathrm{Cl}^{-}$to 5.2 $\mathrm{mM}\left(\mathrm{Ca}^{2+}\right.$ and $\mathrm{Cl}^{-}$were changed proportionally in the other treatment solutions); $\mathrm{Mn}^{2+}$ was decreased in all solutions to 9.1 $\mu \mathrm{M}$ and $\mathrm{Zn}^{2+}$ to $0.8 \mu \mathrm{M}$. These modifications were made to correct a $\mathrm{Ca}^{2+}$ deficiency and an antagonism of $\mathrm{Fe}^{3+}$ uptake by $\mathrm{Mn}^{2+}$ and $\mathrm{Zn}^{2+}$ observed in all treatments of Expt. 1 .

The two plants in the center of each NFT trough were harvested for vegetative tissue analysis 71 DAS at $1000 \mathrm{HR}$. All remaining plants were topped just above the fifth cluster, 113 DAS. The plants were pollinated mechanically and fruit were harvested daily at incipient red until termination of the experiment 176 DAS.

Pulsing-1.5X and $6 X$ solution; fruit and leaves analyzed (Expt. 3). Seeds were sown on 15 Feb. 1991. Seedlings were irrigated with $0.5 \mathrm{X}$ solution beginning 21 DAS. Seedlings were transferred to the NFT system 50 DAS. High EC pulses began 62 DAS. Treatments consisted of the same baseline concentrations as Expts. 1 and 2, but the pulses were increased to $1.5 \mathrm{X}$ and $6 \mathrm{X}$, respectively. The $1 \mathrm{X}$ solution in this study was the same as Expt. 2, except $\mathrm{Mn}^{2+}$ was further decreased to $7.3 \mu \mathrm{M}$ to reduce the antagonism with $\mathrm{Fe}^{3+}$ uptake.

The two plants in the center of each NFT trough were harvested for vegetative tissue analysis 76 DAS at $1000 \mathrm{HR}$. All plants were topped just above the fifth cluster, 102 DAS. Fruit harvest proceeded as in Expt. 2 until termination of the experiment 151 DAS.

Static hydroponic system for Expts. 4-6. Plants with two true leaves were transferred to 42-liter fiberglass tanks containing $1 \mathrm{X}$ solution as used in Expt. 3. The baseline concentration for all the vegetative experiments was $1 \mathrm{X}$. The top dimensions of each tank were $45 \times 64 \mathrm{~cm}$. Each tank contained 35 plants distributed evenly in a $5 \times 7$ arrangement. Two aerators per tank provided mixing and root-gas exchange. Nutrient solutions were changed every 2 weeks. Treatments were applied by lifting the lid of each tank, allowing the roots to drain for $\approx 1 \mathrm{~min}$, and transferring the lid to a tank containing an increased EC 
Table 2. Mean $\mathrm{pH}$, titratable acidity, percent dry matter, SSC, and weight per marketable fruit for fruit of Expts. 2 and 3. ${ }^{\mathrm{Z}}$

\begin{tabular}{|c|c|c|c|c|c|}
\hline $\begin{array}{l}\text { Baseline } \\
\text { nutrient concn }\end{array}$ & $\mathrm{pH}$ & $\begin{array}{c}\text { Titratable } \\
\text { acidity } \\
\left(\mathrm{meq} \cdot 100 \mathrm{ml}^{-1}\right)\end{array}$ & $\begin{array}{c}\text { Dry } \\
\text { matter } \\
(\%)\end{array}$ & $\begin{array}{c}\mathrm{SSC} \\
(\%)\end{array}$ & $\begin{array}{c}\text { Wt per } \\
\text { marketable fruit } \\
(\mathrm{g})\end{array}$ \\
\hline \multicolumn{6}{|c|}{ Expt. 2} \\
\hline $0.25 \mathrm{X}$ & 4.17 & 6.94 & 5.27 & 3.8 & 189 \\
\hline $1 \mathrm{X}^{\mathrm{y}}$ & 4.13 & 7.85 & 5.54 & 4.0 & 174 \\
\hline Significance $^{\mathrm{x}}$ & 0.05 & 0.04 & 0.02 & 0.04 & 0.05 \\
\hline \multicolumn{6}{|c|}{ Expt. 3} \\
\hline $0.25 \mathrm{X}$ & 4.15 & 6.87 & 5.67 & 3.9 & 184 \\
\hline $1 \mathrm{X}$ & 4.13 & 7.01 & 5.94 & 4.0 & 180 \\
\hline Significance $^{\mathrm{x}}$ & 0.03 & 0.33 & 0.04 & 0.11 & 0.66 \\
\hline
\end{tabular}

${ }^{\mathrm{z}}$ Means averaged over pulse and no pulse treatments for each baseline nutrient concentration.

${ }^{\mathrm{y}}$ The $1 \mathrm{X}$ nutrient solution is based on commercial recommendations.

${ }^{\mathrm{x}} \mathrm{p}$ values of $\mathrm{F}$ test; $\mathrm{H}_{\mathrm{o}}$ : Equal means.

solution according to each experimental plan. This process was reversed at the end of a pulse.

$4 X$ solution-30 min pulse and step; leaves analyzed (Expt. 4). Seeds were sown on 15 July 1990. Seedlings were irrigated with $0.5 \mathrm{X}$ solution beginning 10 DAS. Seedlings were transferred to the hydroponic system $20 \mathrm{DAS}$. One group of plants remained in the $1 \mathrm{X}$ baseline concentration solution (control), a second group was transferred to $4 \mathrm{X}$ solution for $30 \mathrm{~min}$ and returned to the $1 \mathrm{X}$ solution (pulse), and a third group was transferred to $4 \mathrm{X}$ solution for the remainder of the experiment (step). The transfers took place 44 DAS at $1130 \mathrm{HR}$. Vegetative tissue was sampled at $0,0.5,1,3,6,24,72$, and $144 \mathrm{~h}$ after the beginning of treatments.

$6 X$ solution-4 $h$ pulse and step; leaves analyzed (Expt. 5). Seeds were sown on 22 Sept. 1990. Seedlings were irrigated with $0.5 \mathrm{X}$ solution beginning 16 DAS. Seedlings were transferred to the hydroponic system 25 DAS. Treatments were the same as Expt. 4 except the pulse-treated plants were transferred to $6 \mathrm{X}$ solution for $4 \mathrm{~h}$ and returned to the $1 \mathrm{X}$ solution, and the step-treated plants were transferred to $6 \mathrm{X}$ solution for the remainder of the experiment. The transfers were accomplished 53 DAS at 1000 HR. Vegetative tissue was sampled 0, 4, 28, 76, and $148 \mathrm{~h}$ after the beginning of treatments.

$6 X$ solution - 4 h pulse; leaves analyzed (Expt. 6). Seeds were sown on 17 Nov. 1990. Seedlings were irrigated with $0.5 \mathrm{X}$ solution beginning 11 DAS. Seedlings were transferred to the hydroponic system 17 DAS. One group remained in the $1 \mathrm{X}$ baseline concentration solution (control) and another was transferred to $6 \mathrm{X}$ solution for $4 \mathrm{~h}$ and returned (pulse). The transfer took place 47 DAS at 0800 HR. Vegetative tissue was sampled $0,3,6,9$, and $24 \mathrm{~h}$ after the beginning of treatments.

Vegetative tissue sampling and chemical analysis. The fifth leaf (blade and petiole) from the apex was selected, composited with similar leaves from other plants(s) in the plot, and weighed. The remainder of the plant was discarded. Leaves were frozen at $-80 \mathrm{C}$ and freeze-dried for analysis. Dried samples were weighed and ground in a stainless steel Wiley mill to a particle size $\leq 1 \mathrm{~mm}$ (20 mesh screen).

Dried tissue was extracted three times in $80 \%(\mathrm{v} / \mathrm{v})$ aqueous ethanol at 80C. An aliquot of supernatant was dried in vacuo at $40 \mathrm{C}$ and resolubilized in water. Fructose in the extracts was reduced with $\mathrm{NaBH}_{4}$, because fructose and malate have similar elution times. A 200- $\mu$ l aliquot of the extract was incubated for $2 \mathrm{~h}$ at $40 \mathrm{C}$ with $100 \mu \mathrm{l}$ of $1.6 \mathrm{~N} \mathrm{NaBH}_{4}$ in $0.25 \mathrm{~N} \mathrm{NaOH}$. Following incubation, $25 \mu \mathrm{l}$ of $7 \mathrm{~N} \mathrm{H}_{2} \mathrm{SO}_{4}$ was slowly added to decompose the remaining $\mathrm{NaBH}_{4}$. Following evolution of $\mathrm{H}_{2}$ gas, samples were centrifuged and frozen for later analysis of organic acids.

The HPLC system for organic acid analysis included either a Waters 6000 or 510 pump (Millipore, Waters Chromatography Division, Milford, Mass.) that delivered the elution solvent, $0.01 \mathrm{~N} \mathrm{H}_{2} \mathrm{SO}_{4}$, at a rate of $0.8 \mathrm{ml} \cdot \mathrm{min}^{-1}$. An $\mathrm{HPX}-87 \mathrm{H}$ column (Bio Rad Laboratories, Richmond, Calif.) was maintained at $65 \mathrm{C}$ and preceded by a microguard cation exchange guard column. Either Waters 401 or 410 refractive index detectors were used. A C-R3A integrator (Shimadzu Corporation, Analytical Instruments Plant, Kyoto, Japan) recorded retention times and peak heights. Sample size was $10 \mu \mathrm{l}$. Organic acids were identified and quantified through comparison with known standards.

Fruit tissue sampling and chemical analysis. All fruit were weighed and examined for defects following harvest at incipient red. Marketable fruit from the first, third, and fifth clusters were ripened for 7 days at 21C. Only first cluster fruit was available in Expt. 1. The ripe fruit were then cut longitudinally in quarters, and two opposite quarters were freeze-dried for percent dry matter determination. The two remaining quarters were frozen and later analyzed for $\mathrm{pH}$, titratable acidity, and soluble solids concentration (SSC). The thawed fruit was pureed and the pulp removed by straining and centrifugation to obtain a clear liquid. The $\mathrm{pH}$ was measured on a $10-\mathrm{ml}$ aliquot. This sample was then titratated to $\mathrm{pH} 8.2$ with $0.1 \mathrm{~N} \mathrm{NaOH}$. SSC was determined with a temperature compensated, hand-held refractometer (American Optical Corp., Keene, N.H.).

Design of experiment and statistical analysis. In Expts. 1-3, each trough was considered an experimental unit. Treatments were arranged in a randomized complete block with three replications. Yield, fruit quality, and vegetative tissue were subjected to analysis of variance (ANOVA) as an $\mathrm{A} \times \mathrm{B}$ factorial with baseline nutrient concentration and no pulse vs. pulse application as factors. Regression models were fitted using a stepwise regression procedure (SAS Institute, Cary, N.C.).

In Expts. 4-6, each hydroponic tank was considered an experimental unit. Treatments were arranged in a randomized complete block with four replications. Vegetative tissue analysis results were subjected to ANOVA.

\section{Results and Discussion}

Pulsing with a high EC solution significantly decreased fruit $\mathrm{pH}$ in Expt. 1 (Table 1). The only effect of baseline concentration on fruit quality was a significant baseline vs. pulse inter- 

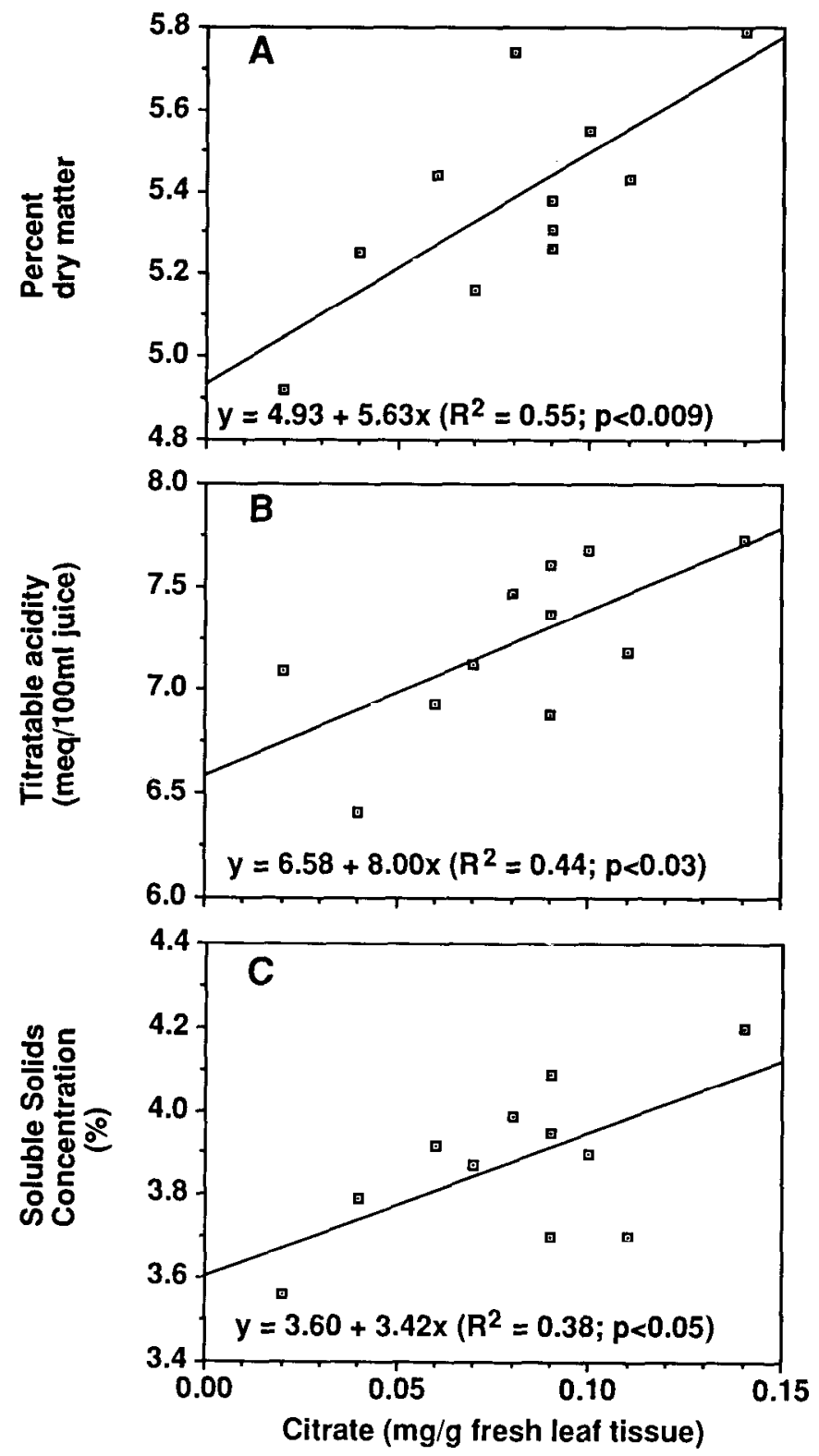

Fig. 1. Tomato fruit percent dry matter (A), titratable acidity (B), and SSC (C) vs. citrate on a fresh weight basis in the fifth leaf from the apex of tomato plants before fruit formation (71 days after seeding) in Expt. 2.

action with respect to titratable acidity $(\mathrm{P}<0.002)$. Titratable acidity increased with pulsing at the $0.25 \mathrm{X}$ level and decreased with pulsing at the $1 \mathrm{X}$ level. Low $\mathrm{pH}$ and high titratable acidity are associated with high fruit quality (Davies and Hobson, 1981). There were no significant differences in SSC (3.5\%), percent dry matter (5.0\%), or weight per marketable fruit (185 and 191 $\mathrm{g}$ for control and pulsed, respectively).

In Expt. 2, pulsing had no effect on any measured characteristics and, thus, data were averaged accordingly. Titratable acidity, SSC, and percent dry matter were higher and $\mathrm{pH}$ was lower at $1 \mathrm{X}$ baseline concentration, as compared to $0.25 \mathrm{X}$ baseline concentration (Table 2). Although these improvements in fruit quality occurred at the higher baseline concentration, weight per marketable fruit decreased. Incidence of BER was 0.4 vs. 1.2 fruit per plant at $0.25 \mathrm{X}$ vs. $1 \mathrm{X}$ baseline concentration $(\mathrm{P}<$ $0.04)$. However, there were no significant differences in mar-

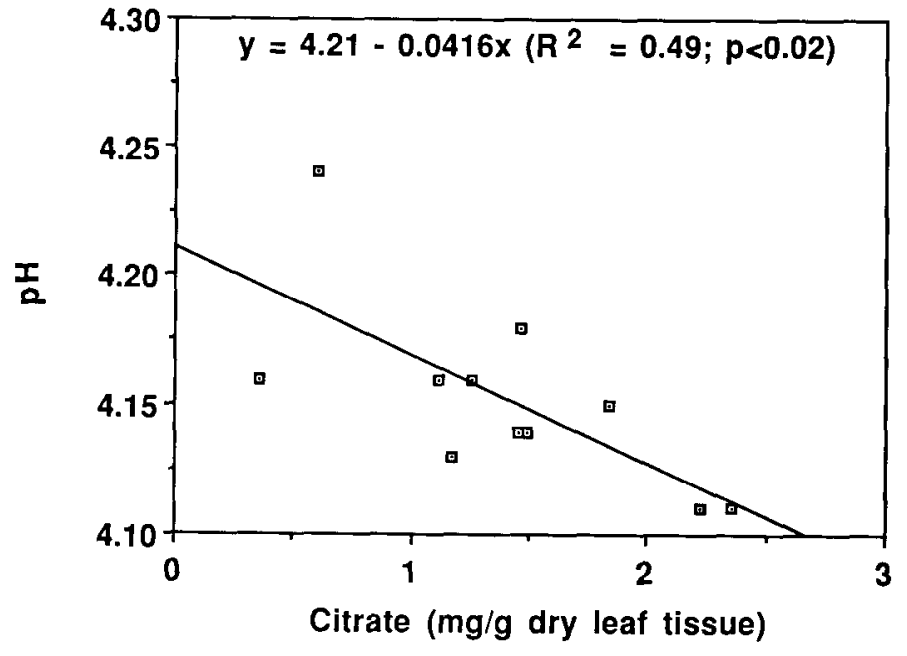

Fig. 2. Tomato fruit pH vs. citrate on a dry weight basis in the fifth leaf from the apex of tomato plants before fruit formation (71 days after seeding) in Expt. 2.

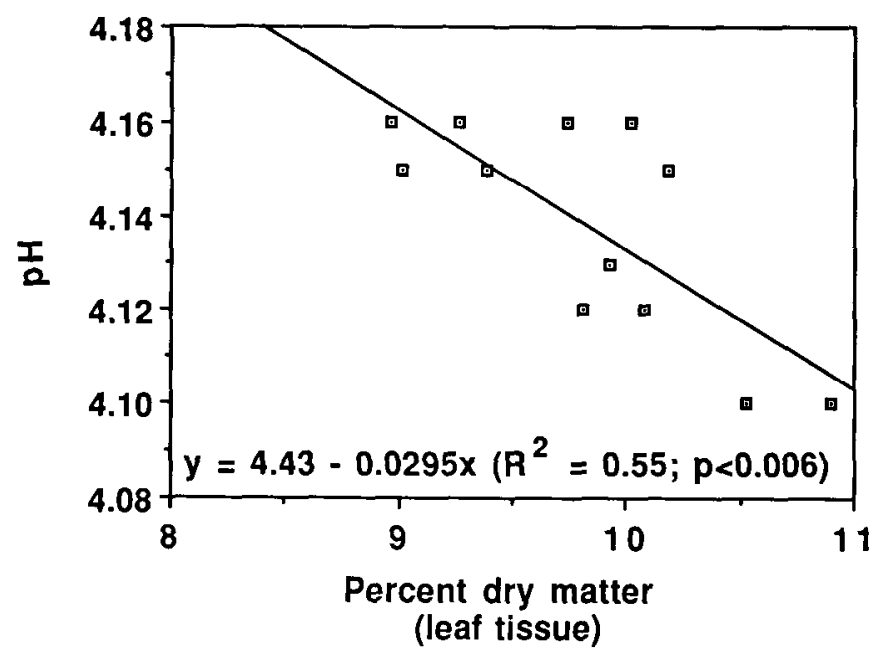

Fig. 3. Tomato fruit $\mathrm{pH}$ vs. percent dry matter in the fifth leaf from the apex of tomato plants before fruit formation (76 days after seeding) in Expt. 3.

ketable yield and number of marketable fruit due to baseline concentration.

In Expt. 3, fruit $\mathrm{pH}$ was lower and percent dry matter higher at the higher baseline concentration (Table 2); however, there were no significant differences in titratable acidity, SSC, or weight per marketable fruit. Pulsing at six times the baseline concentration resulted in a decrease in fruit $\mathrm{pH}$ from 4.15 to 4.12 ( $\mathrm{P}<0.01)$; yet, there were no significant differences in titratable acidity, SSC, percent dry matter, or weight of marketable fruit. There were also no significant differences in marketable yield, number of marketable fruit, or incidence of blossomend rot due to either pulsing or baseline concentration.

Although pulsing caused some changes in fruit quality, these changes were not consistent over all experiments. Lower fruit $\mathrm{pH}$ (Expts. 1 and 3) was the only improvement in fruit quality observed at both baseline concentrations. Although titratable acidity increased with pulsing at the $0.25 \mathrm{X}$ level, the titratable acidity decrease at the $1 \mathrm{X}$ level lowered fruit quality (Expt. 1). The small improvements in fruit quality were not accompanied 
by any yield changes. Since there was no consistent trend, shortterm salt-shocks, as applied in these studies, cannot be recommended as a commercial method to improve fruit quality.

The fruit quality improvements (lower $\mathrm{pH}$, higher titratable acidity, higher percent dry matter, and higher SSC) with the higher EC baseline concentration observed in Expts. 2 and 3 support previous reports (Gough and Hobson, 1990; Massey, et al., 1984). Adams and Ho (1989) observed a reduction in weight per fruit as in Expt. 2. However, total number and marketable yield were not significantly affected in either Expts. 2 or 3. Massey et al. (1984) found no decline in yield with an increasing EC up to $4 \mathrm{mS} \cdot \mathrm{cm}^{-1}$. The EC of the $0.25 \mathrm{X}$ and $1 \mathrm{X}$ solutions were $\approx 0.8$ and $2.8 \mathrm{mS} \cdot \mathrm{cm}^{-1}$, respectively. Our data support the commercial use of long-term increases in the EC of nutrient solutions to improve tomato fruit quality. Subsequent research should refine nutrient concentrations, rates of nutrient concentration change, duration of increased nutrient concentration, and physiological age of plants when long-term increases in the EC of the nutrient solution occur.

In Expt. 2, percent dry matter, titratable acidity, SSC, and $\mathrm{pH}$ in fruit were regressed against citrate, malate, glucose, fructose, sucrose, and percent dry matter in the leaves before fruiting. Percent dry matter, titratable acidity, and SSC in the fruit were positively correlated with the citrate concentration of the fifth leaf on a fresh weight basis in vegetative tomato plants 71 DAS (Fig. 1). Fruit $\mathrm{pH}$ was negatively correlated with leaf citrate concentration on a dry weight basis (Fig. 2). Using these relationships, several vegetative studies could be conducted in the same time as one complete fruiting study. The significant predictive relationships in Expt. 2 were explored in three experiments where leaves were analyzed (Expts. 4-6).

In Expt. 4, no changes in leaf citrate, either on a fresh or dry weight basis, were observed as a result of the $4 \mathrm{X}$ pulse or the $4 \mathrm{X}$ step treatments. In Expt. 5, the pulse concentration and duration were increased to $6 \mathrm{X}$ and $4 \mathrm{~h}$, respectively, to increase the salt-stress level; but no changes in leaf citrate were observed as a result of the pulse or step treatments. However, leaf citrate levels decreased in the afternoon in all treatments while malate increased. Apparently, malate and citrate in tomato leaves fluctuate diurnally, as was later verified (Niedziela, 1992). As a result, citrate was difficult to detect in the afternoon. Expt. 6 was conducted to determine if any differences in leaf citrate levels could be detected in the morning (0800 HR) following a pulse, when leaf citrate levels would be expected to be high, but no significant differences in leaf citrate due to the pulse were observed. From these data, we concluded that tomato leaf citrate is not a good predictor of subsequent fruit quality.

In Expt. 3, fruit $\mathrm{pH}$ was negatively correlated with the percent dry matter of the fifth leaf in vegetative plants 76 DAS (Fig. $3)$. There were no significant relationships between the other fruit quality characteristics and either organic acids or percent dry matter in the fifth leaf. Although the percent dry matter in the fifth leaf was correlated with the subsequent fruit quality, the dry matter content can change diurnally due to such physiological processes as starch accumulation and degradation. As noted, tomato leaf citrate levels also change diurnally. Before conducting further predictive studies on vegetative tomato plants with the goal of improved fruit quality, a more stable predictor needs to be identified.

\section{Literature Cited}

Adams, P. and L.C. Ho. 1989. Effects of constant and fluctuating salinity on the yield, quality and calcium status of tomatoes. J. Hort. Sci. 64:725-732.

Bruggink, G.T., H.E. Schouwink, and E.A.J.M. Coolen. 1987. Effects of different day and night osmotic pressure of nutrient solutions on growth, water potentials and osmotic potentials of young tomato plants in soilless culture. Soilless Cult. 3(2):9-19.

Cooper, A.J. 1985. New ABC's of NFT, p. 180-185. In: A.J. Savage (ed.). Hydroponics worldwide: State of the art in soilless crop production. Intl. Ctr. Spec. Studies, Honolulu.

Davies, J.N. and G.E. Hobson. 1981. The constituents of tomato fruitthe influence of environment, nutrition, and genotype, p. 205-280. In: T.E. Furia (ed.). CRC Critical reviews in food science and nutrition. vol. 15. CRC Press, Boca Raton, Fla.

Edwards, K. 1985. New NFT breakthroughs and future directions, p. 186-192. In: A.J. Savage (ed.). Hydroponics worldwide: State of the art in soilless crop production. Intl. Ctr. Spec. Studies, Honolulu.

Gough, C. and G.E. Hobson. 1990. A comparison of the productivity, quality, shelf-life characteristics and consumer reaction to the crop from cherry tomato plants grown at different levels of salinity. J. Hort. Sci. 65:431-439.

Hall, D.A. and G.C.S. Wilson. 1986. The development of hydroponic culture in Scotland. Res. Dev. Agr. 3(2):61-69.

ICI Midox. n.d. 'Solufeed' a balanced fertilizer for crop production in rockwool, perlite, U.F. foam and the nutrient film technique. Tech. Info. Bul. no. 82. ICI Midox, Surrey, United Kingdom.

Massey, D.M., A.C. Hayward, and G.W. Winsor. 1984. Some responses of tomatoes to salinity in nutrient-film culture. Annu. Rpt. Glasshouse Crops Res. Inst. 1983.

Mitchell, J.P., C. Shennan, S.R. Grattan, and D.M. May. 1991. Tomato fruit yields and quality under water deficit and salinity. J. Amer. Soc. Hort. Sci. 116:215-221.

Mizrahi, Y. 1982. Effect of salinity on tomato fruit ripening. Plant Physiol. 69:966-970.

Mizrahi, Y., S.M. Arad, and R. Zohar. 1986. Salinity as a possible means of improving fruit quality in slow-ripening tomato hybrids. Acta Hort. 190:223. (Abstr.)

Mizrahi, Y. and D. Pasternak. 1985. Effect of salinity on quality of various agricultural crops. Plant \& Soil 89:301-307.

Mizrahi, Y., E. Taleisnik, V. Kagan-Zur, Y. Zohar, R. Offenbach, E. Matan, and R. Golan. 1988. A saline irrigation regime for improving tomato fruit quality without reducing yield. J. Amer. Soc. Hort. Sci. 113:202-205.

Niedziela, C.E., Jr. 1992. Role of substrate nutrient flux in tomato fruit quality. PhD Diss., North Carolina State Univ., Raleigh. (Diss. Abstr. 9211836.)

Rains, D.W. and R.C. Valentine. 1980. Biological strategies for osmoregulation, p. 1-5. In: D.W. Rains, R.C. Valentine, and A. Hollaender (eds.). Genetic engineering of osmoregulation. Plenum Press, New York. 